\title{
EFFECTS OF ROOT DEFORMATION AND LIGHT AVAILABILITY ON GROWTH AND BIOMASS ALLOCATION OF Senna multijuga SEEDLINGS (Rich) H. S. Irwin \& Barneby
}

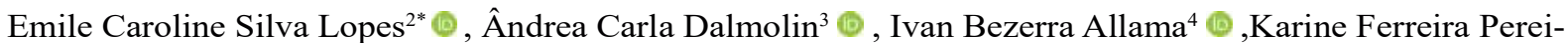

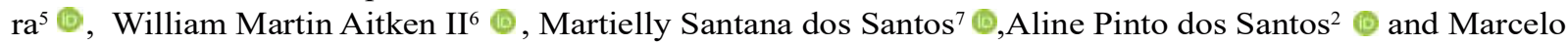 \\ Schramm Mielke 70
}

\footnotetext{
${ }^{1}$ Received on 03.09.2019 accepted for publication on 12.05.2020.

${ }^{2}$ Universidade Estadual de Santa Cruz, Programa de Pós-Graduação em Produção Vegetal, Ilhéus, BA- Brasil. E-mail:<emilecarolineufrb@, yahoo.com.br> and <apsantos_florestal@hotmail.com>.

${ }^{3}$ Universidade Federal do Sul da Bahia, Centro de Formação em Ciências Agroflorestais, Ilhéus, BA- Brasil. E-mail: <andreacarlad@ gmail.com>.

${ }^{4}$ Universidade Estadual de Santa Cruz, Departamento de Ciências Exatas e Tecnológia, Ilhéus, BA- Brasil. E-mail: <iballaman@uesc.br>.

${ }^{5}$ Universidade Estadual de Santa Cruz, Graduada em Ciências Biológicas, Ilhéus, BA- Brasil. E-mail: < karinee.2112@gmail.com>

${ }^{6}$ Universidade Estadual de Santa Cruz, Graduado em Ciências Biológicas, Ilhéus, BA- Brasil. E-mail: <wmartin@uesc.br>.

${ }^{7}$ Universidade Estadual de Santa Cruz, Departamento de Ciências Biológicas, Ilhéus, BA- Brasil. E-mail: <martiellysantana@gmail.com> and $<$ msmielke@uesc.br>.

*Corresponding author.
}

\begin{abstract}
The effects of root deformation caused by errors in the pricking-out process in forest nurseries are still unknown for tropical tree seedlings. We analyzed the effects of light availability and root deformation on growth and biomass allocation in seedlings of Senna multijuga, a pioneer tropical tree commonly used in forest restoration programs. Our hypotheses were: (a) as a typical light-demanding species, the seedlings of $S$. multijuga may have their growth compromised by low light availability; (b) root deformation impairs growth rates and induces changes in biomass allocation; and (c) the effects of low light availability on growth and biomass allocation are increased by root deformation. Seedlings with and without root deformation were cultivated for 43 days under three levels of total daily photosynthetically active radiation (PAR) (28, 12, and 1 mol photons $\mathrm{m}^{-2}$ day $^{-1}$ ). Seedlings of $S$. multijuga had their growth rates severely affected by values of PAR at about 1 mol photons $\mathrm{m}^{-2}$ day $^{-1}$, but root deformation did not affect the relative growth rates of the whole plant. Instead, root deformation caused a decrease in the relative growth rate of roots in all light availabilities. The changes in root growth affected biomass allocation to the roots. The interactive effects of light availability and root deformation on the allocation of biomass to leaves are more pronounced at low light availability. Root deformations may lead to the production of seedlings with a low competitiveness capacity regardless of light conditions.
\end{abstract}

Keywords: Brazilian Atlantic Rainforest; Pricking-out; Seedling quality.

\section{EFEITOS DA DEFORMAÇÃO RADICULAR E DA DISPONIBILIDADE DE LUZ NO CRESCIMENTO E NA DISTRIBUIÇÃO DE BIOMASSA DE MUDAS DE Senna multijuga (Rich) H. S. Irwin \& Barneby}

\begin{abstract}
RESUMO - Os efeitos e consequências da deformação da raiz causada por erros no processo de repicagem em viveiros florestais ainda são desconhecidos para as mudas de árvores tropicais. Analisamos os impactos da disponibilidade de luz e de deformação das raizes no crescimento e alocação de biomassa em mudas de Senna multijuga, uma árvore tropical pioneira comumente utilizada em programas de restauração florestal. Nossas hipóteses foram: (a) como espécie típica exigente de luz, as plântulas de $\boldsymbol{S}$. multijuga podem ter seu crescimento comprometido em baixa disponibilidade de luz, (b) a deformação da raiz induz prejuizos nas taxas de crescimento e mudanças na alocação de biomassa, e (c) os efeitos da baixa disponibilidade de luz
\end{abstract}

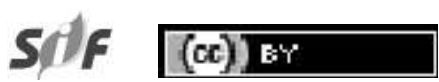

Revista Árvore 2020;44:e4418 http://dx.doi.org/10.1590/1806-908820200000018 


\begin{abstract}
no crescimento e alocação de biomassa são potencializados pela deformação da raiz. As plântulas, com e sem deformação das raizes, foram cultivadas durante 43 dias sob três níveis de radiação fotossinteticamente ativa total (PAR) $\left(28,12\right.$ e 1 mol fótons $\mathrm{m}^{-2}$ dia $\left.{ }^{-1}\right)$. Mudas de $\boldsymbol{S}$. multijuga tiveram suas taxas de crescimento severamente afetadas nos valores de PAR em cerca de 1 mol fótons $m^{-2}$ dia-1, mas a deformação das raízes não afetou as taxas de crescimento relativo da planta inteira. Em vez disso, a deformação da raiz causou uma diminuição na taxa de crescimento relativo das raizes em todas as disponibilidades de luz. As mudanças no crescimento das raizes afetaram a alocação de biomassa para as raízes. Os efeitos da disponibilidade de luz e da deformação da raiz na alocação de biomassa para folhas são mais pronunciados a baixos valores de disponibilidade de luz. As deformações das raizes poderiam levar à produção de mudas com baixa capacidade de competitividade independentemente das condições de luz.
\end{abstract}

Palavras-Chave: Mata Atlântica; Repicagem; Qualidade de mudas.

\section{INTRODUCTION}

Forest degradation in the tropics has caused the loss of habitats for flora and fauna and has been promoted through anthropic activities, such as logging, hunting, and deforestation for agricultural expansion (Calegari et al., 2010; Giam, 2017). In this context, forest restoration represents an important way to mitigate the environmental problems caused by forest degradation (Lamb, 2012; Brancalion and Chazdon, 2017). One of the most important steps in the establishment of forest stands is to ensure quality seedling production at the nursery stage because this directly affects seedling establishment and growth in the field (Binotto et al., 2010; Grossnickle, 2016). Due to the initial fragility of tree seedlings, the seedling production process requires appropriate management strategies in the nursery to obtain a better uniformity of height and a well-formed root system because these qualities can promote satisfactory survival and growth in the field, even under adverse conditions (Gomes et al., 2002; Thomas et al., 2008).

Plants depend on their roots for soil anchorage and the absorption of water and nutrients (Lynch, 1995; Amoroso et al., 2010). Roots also need to be capable of acquiring resources efficiently and penetrating the soil, even under conditions of compaction and mechanical resistance (Bizet et al., 2016). Root deformations can be induced at three stages of seedling production in the nursery, that is, in the stages of pricking-out, growth, and harvesting. The deformation of roots in the prickingout process occurs when the hole made in the substrate to accommodate the roots is smaller than the root's total length. Although the use of containers with inadequate size and form and the time spent in the nursery can promote deformations in the root system, the pricking out process is crucial because errors during this process are irreversible (Carneiro, 1995; Jaenicke, 1999; Wendling et al., 2002; Gregorio et al., 2010; Wilkinson et al., 2014; Duboc, 2015). Root deformations reduce the absorption and translocation of water and nutrients, as deformation points can offer resistance to hydraulic conductivity and indirectly cause nutritional imbalance, compromising the establishment and competitiveness of field tree seedlings (Reis et al., 1991). Low competitiveness capacity may lead to the impairment of plant growth and mortality (Ortega et al., 2006), resulting in higher costs for the maintenance of forest stands with the replacement of new seedlings (Freitas et al., 2005). Root deformation caused at the moment of seedling pricking out is a problem in small- and medium-sized nurseries in the tropics. Although several nursery manuals draw attention to problems arising from root deformation at the time of pricking out (Carneiro, 1995; Jaenicke, 1999; Gregorio et al., 2010; Wilkinson et al., 2014), the topic has never been the focus of intensive experimental studies or the subject of experiments on the interactive effects of root deformation and environmental stress.

The opening and closing of gaps in the developing forest favor the formation of light gradients, making creating ideal conditions for the occurrence of a great diversity of plant species (Valladares et al., 2012). Plants of the early and intermediate stages of forest succession are typically light-demanding. Well-adapted to deal with high light intensities, they have a great capacity to survive and grow in gaps and forest edges (Bazzaz and Picket, 1980; Whitmore, 1989). Typically, pioneer tree species have mechanisms that enable them to tolerate excess light but exhibit limited ability to establish and grow under low light availability (Kitajima and Fenner, 2000). Pioneer tree species grow rapidly and are suitable for planting in projects to restore degraded forests (Montagnini, 2005).

Revista Árvore 2020;44:e4418 
Senna multijuga belongs to the Leguminosae family (Carvalho, 2004). In Brazil, this species is distributed in almost all regions of the country, especially in the Brazilian Atlantic rainforests (Lorenzi, 2002). It is classified as a pioneer species, demanding light and being indifferent to the physical conditions of the soil (Lorenzi, 2002). This species has high growth rates and is recommended for planting in mixed reforestation schemes for degraded areas (Lorenzi, 2002; Carvalho, 2004; Doust et al., 2006). The fact that $S$. multijuga has a short life cycle compared to other forest species, plus the ability to colonize poor soils rapidly and disperse its seeds by autochory, makes it suitable for use in forest restoration programs (Lacerda et al., 2004).

In this study, we analyzed the effects of light availability and root deformation on growth and biomass allocation in S. multijuga seedlings. Our hypotheses were as follows: (a) as a typical light-demanding species, the seedlings of S. multijuga may have their growth compromised by low light availability; (b) root deformation impairs growth rates and induces changes in biomass allocation; and (c) the effects of low light availability on growth and biomass allocation are increased by root deformation.

\section{MATERIALS AND METHODS}

Seeds of S. multijuga were collected by the Instituto Floresta Viva (IFV) from trees located in the district of Serra Grande, Uruçuca, Bahia, Brazil (14046'59"'S, 39o02'39"W). The experiment was installed in the nursery of the Universidade Estadual de Santa Cruz (UESC), Ilhéus, BA, Brazil (14045'15"'S, 39013 '59' W). The UESC's nursery measures $20 \times$ $15 \mathrm{~m}$ and is covered with a shade cloth that allows the passage of approximately $60 \%$ of light radiation at full sun. Seeds were planted in plastic boxes containing washed sand. One month after germination, seedlings were pricked out to plastic bags with a capacity of 1.5 L. The soil used had been collected from a small area of forest located on the UESC campus. At the moment of pricking out, the roots of $50 \%$ of the seedings were deliberately deformed. The deformation of roots was carried out by bending the root towards the stem and forcing the fold to $180^{\circ}$ (Figure 1). Also, the hole for root accommodation was approximately half the total length of the main root. After 21 days of acclimation, the plastic bags were placed inside PVC tubes of $100 \mathrm{~mm}$ diameter and $250 \mathrm{~mm}$ height and transferred to three different light availability conditions.

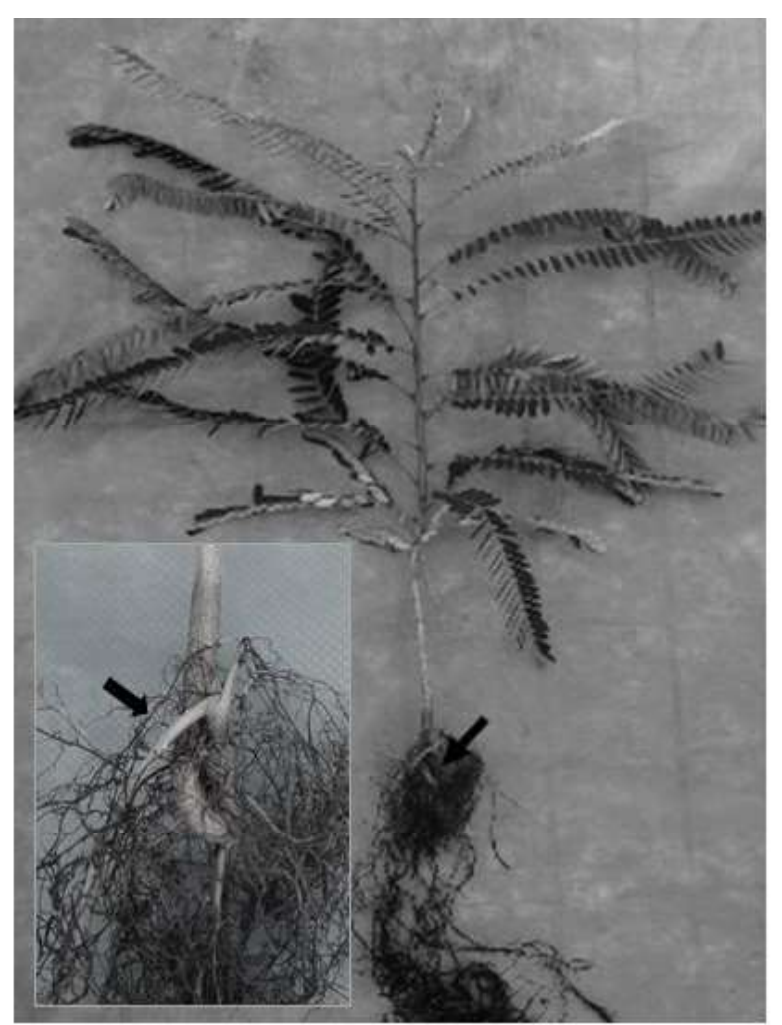

Figure 1 - Seedling of S. multijuga with root deformation. The arrow indicates where the deformation occurs. Source: Authors.

Figura 1 - Mudas de S. multijuga com deformação radicular. A seta indica onde ocorre a deformação. Fonte: Autores.

Seedlings without (R1) and with (R2) root deformation were distributed in three conditions of light availability, repeated three times each. Light conditions were obtained by constructing shaded houses with $1 \mathrm{~m}$ wide $\times 1 \mathrm{~m}$ long $\times 0.80 \mathrm{~m}$ high, covered with different layers of shade cloths. The shade houses were then arranged randomly on three wooden and metal benches with $1 \mathrm{~m}$ height and $4.0 \times 1.5 \mathrm{~m}$ area, so as to have a replica of each light environment per bench. Throughout the experiment, the photosynthetically active radiation (PAR) was measured using S-LIA-M003 light sensors coupled to Hobo Micro Station Data Loggers (Onset Computer, Massachusetts, USA). The data loggers were programmed to perform readings at 1 -second intervals and to store the mean PAR values every $10 \mathrm{~min}$. During the experiment, the average daily total PAR was 28 , 12 , and 1 mol photons $\mathrm{m}^{-2}$ day ${ }^{-1}$, respectively, for the three light environments. Air temperature and relative humidity were monitored inside the nursery using a

Revista Árvore 2020;44:e4418 
Hobo Pro V2 Data Logger sensor (Onset Computer, Massachusetts, USA). The average daytime temperature was $27.5^{\circ} \mathrm{C}$ and the average nighttime temperature was $23.8^{\circ} \mathrm{C}$, and the maximum and minimum temperatures were $31.6{ }^{\circ} \mathrm{C}$ and $23.1{ }^{\circ} \mathrm{C}$, respectively. The average daily vapor pressure (DPV) deficit was $0.81 \mathrm{kPa}$.

At the beginning of the experiment, when plants were transferred to the light environment, $\left(\mathrm{RDM}_{1}\right)$, stems $\left(\mathrm{SDM}_{1}\right)$, leaves $\left(\mathrm{LDM}_{1}\right)$ and total dry mass (TDM) were evaluated for 10 seedlings with root deformation and 10 seedlings without root deformation. Dry masses of roots, stems, and leaves were obtained by drying plant parts in an air-circulating oven at $50{ }^{\circ} \mathrm{C}$ until a constant dry mass was obtained. At 43 days after the beginning of the experiment, measures of plant height $(\mathrm{H})$ and diameter (D) were measured. The plants were removed from the substrate, and the root volume (RV) was measured by the displaced water method using a 500 $\mathrm{mL}$ measuring beaker. The plants were then separated into roots, stems, and leaves for the determination of $\mathrm{RDM}_{2}, \mathrm{SDM}_{2}, \mathrm{LDM}_{2}$, and $\mathrm{TDM}_{2}$. From these values, the following variables were calculated:

root mass ratio $R M R_{2}=\frac{R D M_{2}}{T D M_{2}}$, stem mass ratio $S_{S M R_{2}}=\frac{S D M_{2}}{T D M_{2}}$, and leaf mass ratio $L M R_{2}=\frac{L D M_{2}}{T D M_{2}}$, relative growth rate basied on total plant dry mass $R G R=\frac{\operatorname{In} T D M_{2}-\text { In } T D M_{1}}{43}$, relative growth rate based on leaf mass, $R G R_{L}=\frac{\ln L D M_{2}-\ln L D M_{1}}{43}$ relative growth rate based on stem dry mass ${ }_{R G R_{S}=}=\frac{\ln S D M_{2}-\ln S D M_{1}}{43}$, and relative growth

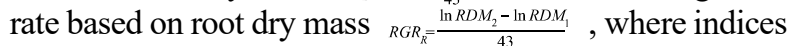
1 and 2 correspond to the evaluations performed at the end and at the beginning of the experiment, respectively, and 43 days was the duration of the experiment. Based on data of $\mathrm{H}, \mathrm{D}, \mathrm{RDM}$, and RV, we calculated the ratios of $\mathrm{D} / \mathrm{H}, \mathrm{D} / \mathrm{RV}$, and $\mathrm{H} / \mathrm{RV}$.

The experiment was conducted in a randomized block design, in a split-plot scheme, with and without root deformation and three light availabilities (28, 12 and $1 \mathrm{~mol}$ photons $\mathrm{m}^{-2}$ day $^{-1}$ ) with four to five plants per experimental unit. The data were submitted to analysis of variance (ANOVA) followed by Tukey's test at a 5\% significance level. All assumptions about the residuals were tested, and when there were violations, the Box-Cox transformation was used. Statistical analyses were carried out using R software (R Development Core Team, 2019) with the Tinn-R interface (Tinn-R Team, 2018).

\section{RESULTS}

For the variables $\mathrm{H}, \mathrm{D}, \mathrm{RGR}, \mathrm{RGR}_{\mathrm{S}}, \mathrm{RGR}_{\mathrm{R}}, \mathrm{SMR}_{2}$, $\mathrm{RMR}_{2}, \mathrm{D} / \mathrm{H}, \mathrm{D} / \mathrm{RV}$, and $\mathrm{H} / \mathrm{RV}$, there were no significant

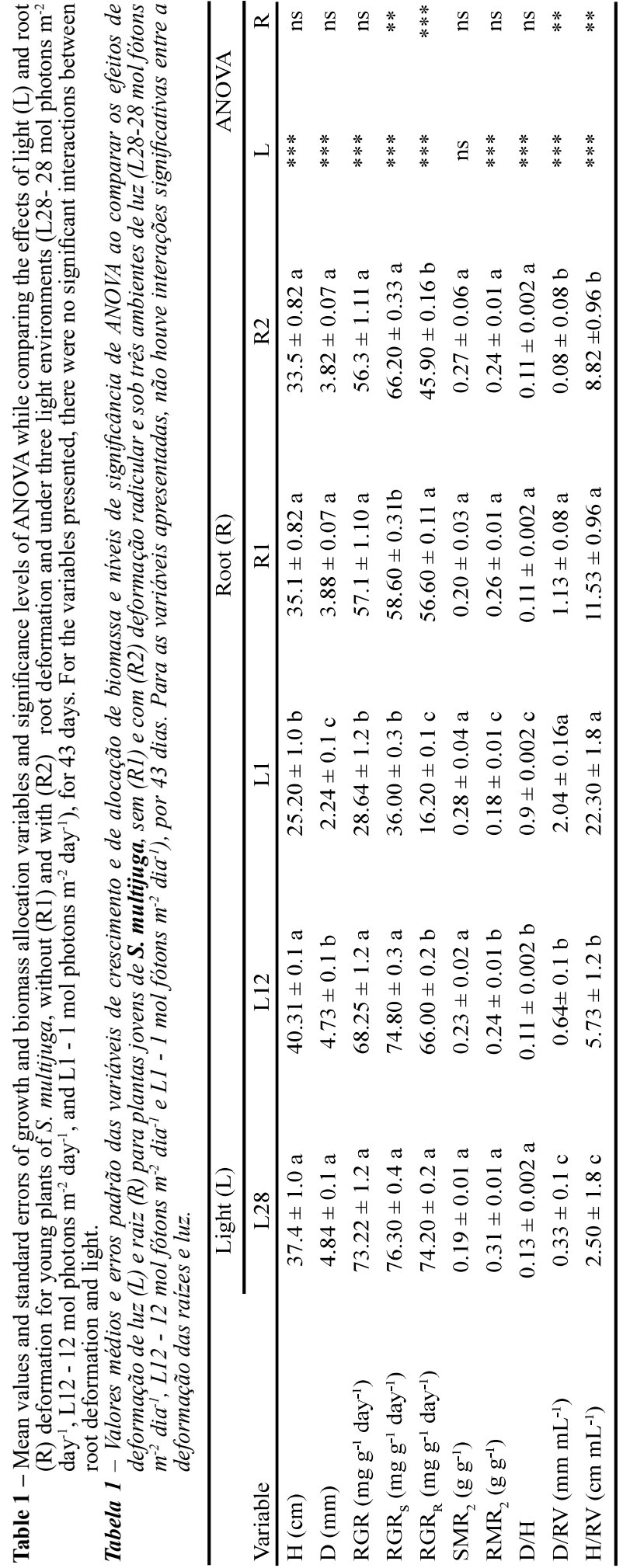

Revista Árvore 2020;44:e4418 
effects of the interactions between light and $\operatorname{root}(\mathrm{p}>0.05)$ (Table1). Seedlings of S. multijuga showed severely affected PAR values at about $1 \mathrm{~mol}$ photons $\mathrm{m}^{-2}$ day${ }^{1}$. With the exception of $\mathrm{SMR}_{2}$, significant differences between light environments were found for all variables analyzed. For $\mathrm{H}, \mathrm{RGR}$, and $\mathrm{RGR}_{\mathrm{S}}$, non-significant differences were found between L28 and L12. The mean values of $\mathrm{D}, \mathrm{RGR}_{\mathrm{R}}, \mathrm{RMR}_{2}$, and $\mathrm{D} / \mathrm{H}$ were significantly higher in L28 than in L12 and L1, whereas the mean values of $\mathrm{D} / \mathrm{RV}$ and $\mathrm{H} / \mathrm{RV}$ were significantly higher in L1 than in L28 and L12. The mean values of RGR, $\mathrm{RGR}_{\mathrm{S}}$, and $\mathrm{RGR}_{\mathrm{R}}$ were 2.6, 2.1 and 4.6 times higher in L28 than in L1. The mean values of $\mathrm{D} / \mathrm{RV}$ and H/RV were respectively 6.2 and 8.9 times higher in $\mathrm{L} 1$ than in $\mathrm{L} 28$.

For $\mathrm{RGR}_{\mathrm{L}}$ and $\mathrm{LMR}_{2}$, significant interactions were verified between root condition and light environment $(p<0.05)$. The lowest averages were presented in the condition of lower light availability (L1). Plants without deformation presented 2.0 times higher values for $\mathrm{RGR}_{\mathrm{L}}$ in L28 compared to L1 (Table 2), whereas plants with deformation were 3.0 times higher in L28 than in L1. On the other hand, the mean values of $\mathrm{LMR}_{2}$ in plants without root deformation (R1) were significantly higher than in plants with root deformation (R2) in L1. In this lower light environment (L1), the mean values of $\mathrm{LMR}_{2}$ in R1 were 1.3 times higher than in R2 (Table 2).

For biomass allocation, R1 and R2 had less root biomass in L1 (Figure 2). Nevertheless, the biomass allocation to the stems was much higher in R2 than in the other factorial combinations (roots $\mathrm{x}$ light availability). The highest biomass allocation to the leaves was observed in R1 in L1, while the highest biomass allocation to the roots was observed in L28, independent of root deformation. Plants without root deformation (R1) had approximately $70 \%, 72 \%$, and $80 \%$ of biomass allocated to leaves and stems in L28, L12, and L1, respectively. In comparison, plants with root deformation (R2) had about $70 \%, 79 \%$, and $90 \%$ of biomass allocated to leaves and stems in L28, L12, and $\mathrm{L} 1$, respectively. The lowest biomass allocated to the roots was observed for $\mathrm{R} 2$ in $\mathrm{L} 1$.

\section{DISCUSSION}

The significant differences in $\mathrm{H}, \mathrm{RGR}$, and $\mathrm{RGR}_{\mathrm{S}}$ of seedlings in L28 and L12 in comparison with seedlings in L1 indicate that $S$. multijuga is a typical light-demanding and shade-intolerant species, in accordance with its ecological classification (Lorenzi, 2002). Significant differences in $\mathrm{RMR}_{2}$ in plants grown in L28 in comparison with L12 and L1 are related to the characteristics of acclimatization to low light availability. Plants grown under low light availability tend to allocate more biomass to stems and leaves than to the roots (Montgomery, 2004; Valladares et al., 2012). This tendency can be more easily observed in fastgrowing pioneer species, reinforcing the classification of $S$. multijuga as a light-demanding species. Increases in the biomass allocation to leaves in relation to stems and roots contribute to the maintenance of a positive carbon balance in counterparts with low photosynthetic capacity under low light availability (Givnish, 1988). In contrast, plants grown in environments with higher light intensity tend to have higher transpiration rates, and there is usually an increase in carbon allocation to the roots to increase the efficiency of water and nutrient absorption (Poorter, 1990; Zuidema et al., 1999; Poorter et al., 2012). Due to the high levels of irradiance, the air temperature rises, which can cause water restriction in the soil. As a strategy to escape water stress, plants

Table 2 - Mean values and standard errors of relative growth rate based on leaf dry mass (RGR $)$ and leaf mass ratio (LMR $)$ of $S$. multijuga

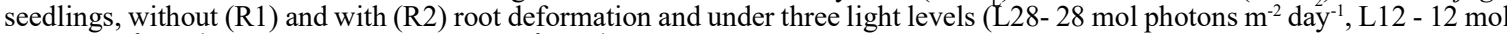
photons $\mathrm{m}^{-2}$ day $^{-1}$, and L $1-1$ mol photons $\mathrm{m}^{-2}$ day $\left.^{-1}\right)$, at the end of 43 days.

Tabela 2 -Valores médios e erros padrão da taxa de crescimento relativo com base na massa seca das folhas ( $R G R$ ) e da razão da massa foliar (LMR) de mudas de $\boldsymbol{S}$. multijuga, sem (R1) e com (R2) deformação das raízes e sob três níveis de luz (L28-28 mol fótons $m^{-2}$ dia $a^{-1}$ L12 - 12 mol fótons $m^{-2}$ dia ${ }^{-1}$, e L1 - 1 mol fótons $m^{-2}$ dia $\left.^{-1}\right)$, ao final de 43 dias.

\begin{tabular}{lcccc}
\hline Variable & Root & L28 & L12 & L1 \\
\hline RGR $_{\mathrm{L}}$ & $\mathrm{R} 1$ & $70.20 \pm 0.2 \mathrm{Aa}$ & $69.70 \pm 0.2 \mathrm{Aa}$ & $0.51 \pm 0.02 \mathrm{Ba}$ \\
& $\mathrm{R} 2$ & $63.10 \pm 0.2 \mathrm{Aa}$ & $67.70 \pm 0.2 \mathrm{Aa}$ & $0.48 \pm 0.03 \mathrm{Cb}$ \\
LMR $_{2}$ & $\mathrm{R} 1$ & $34.40 \pm 0.2 \mathrm{Ba}$ & $23.10 \pm 0.2 \mathrm{Ba}$ & $0.64 \pm 0.03 \mathrm{Aa}$ \\
& $\mathrm{R} 2$ & $0.51 \pm 0.02 \mathrm{Ca}$ & $0.57 \pm 0.03 \mathrm{Aa}$ & $0.52 \pm 0.03 \mathrm{Bb}$ \\
\hline Means followed by the
\end{tabular}

Means followed by the same letter are not significantly different from each other by the Tukey test $(\mathrm{p}<0.05)$. Capital letters represent comparisons between light

environments within root conditions and lowercase letters represent comparisons between root conditions for each light environment.

Médias seguidas da mesma letra não são significativamente diferentes entre si pelo teste de Tukey $(p<0,05)$. Letras maiúsculas representam comparações entre ambientes de luz dentro das condições de raiz e letras minúsculas representam comparações entre as condições raiz para cada ambiente de luz. 


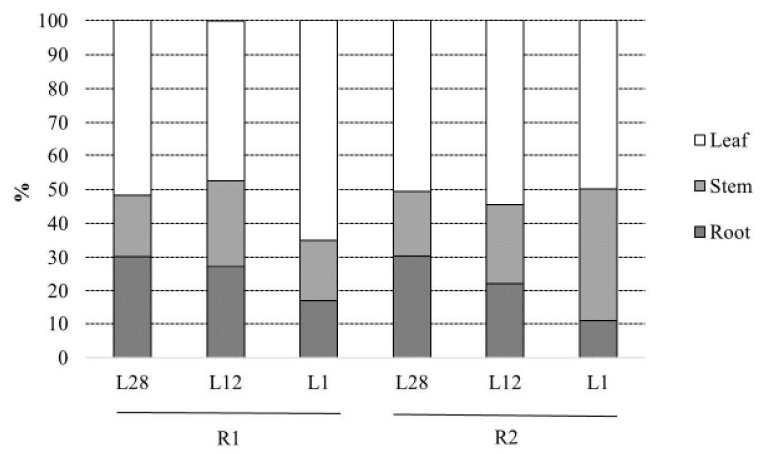

Figure 2 - Biomass allocation for leaves, stems and roots in seedlings of $S$. multijuga, without (R1) and with (R2) root deformation and subjected to three light levels (L28- 28 mol photons $\mathrm{m}^{-2}$ day $^{-1}, \mathrm{~L} 12$-12 mol photons $\mathrm{m}^{-2}$ day $^{-1}$, and L1-1 mol photons $\mathrm{m}^{-2}$ day $^{-1}$ ) during 43 days.

Figura 2 - Alocação de biomassa para folhas, caules e raízes em mudas de $\boldsymbol{S}$. multijuga, sem (R1) e com (R2) deformação da raiz e submetidos a três níveis de luz (L28-28 mol fótons $m^{-2}$ dia ${ }^{-1}$, L12-12 mol fótons $\mathrm{m}^{-2}$ dia $^{-1}$, e L1-1 mol fótons $\mathrm{m}^{-2}$ dia-1) durante 43 dias.

invest in root growth, seeking the deepest and most humid layers in the soil (Scalon et al., 2011). Plants of S. multijuga occur naturally in several regions of Brazil, including the dry forests of the northeastern Brazilian interior, which are characterized by pronounced climatic seasonality, with well-defined dry and rainy seasons (Carvalho, 2004). Therefore, the increase in the allocation of biomass to the roots in environments with higher light availability is a strategy to maintain the water balance because, at high solar radiation and high temperatures, plants tend to transpire more (Markesteijn and Poorter, 2009).

The low mean $R_{G R}$ values probably triggered low $\mathrm{RGR}_{\mathrm{L}}$ values, as the lower biomass allocation to the roots decreases water and nutrient uptake, affecting photosynthesis and the availability of carbon for leaf growth. In this case, the decrease in net photosynthetic rates is a common response of light-demanding trees to low light availability. In such cases, the leaves cannot adjust to the PAR available and cannot reach their maximum photosynthetic capacity (Feijó et al., 2009). Also, root deformation can increase resistance to water flows and nutrients. This low capacity for transporting carbohydrates to non-photosynthetic tissues and increasing resistance to water and nutrient flows from roots to leaves can cause significant changes in $R_{R}$ in plants with root deformation regardless of the light condition in which they were grown. At the same time, the reduction in light availability also caused the reduction of $\mathrm{RGR}_{\mathrm{R}}$ regardless of root conditions. In addition to the phloem transport of carbohydrates from the leaves to the roots, the supply of minerals from the root to the leaves also affects carbon assimilation and partitioning, influencing the ratio of root to shoot biomass (Agren and Ingestad, 1987). In fact, root and shoot growth depend on a closely coordinated balance (Farrar and Jones, 2000), and environmental factors, such as availability of water, minerals, and light, can modify the root/shoot biomass ratio (McDonald et al., 1986). Thus, endogenous and exogenous factors, such as root deformation and low light availability, can drastically affect leaf and root growth, as observed in the experiment in seedlings with root deformation in L1.

Seedlings with root deformation are less able to compete for water and nutrient uptake and have less soil anchorage capacity. For example, in degraded tropical pastures, the death of tree seedlings due to competition for light, water, and nutrients with fast-growing grasses is a constant risk factor (Resende and Leles, 2017). In tropical regions, degraded pastures are often covered with fast-growing grasses, such as species of the genus Brachiaria spp. and Urochloa decumbens, which can reach up to $1.5 \mathrm{~m}$ in height and are difficult to control (Weidlich, 2011; Ferreira et al., 2016). Therefore, in the first months after planting, intensive mechanical and chemical weeding around seedlings are necessary to avoid and control the competition for light, water, and nutrients with native and exotic spontaneous plants (César et al., 2014; Santos et al., 2018). Weeding represents a significant part of maintenance costs in forest restoration projects, and the procedures used to control the competition of tree seedlings with fastgrowing plants are sometimes inefficient and costly (Brancalion et al., 2009). Thus, the poor quality of tree seedlings caused by errors in the pricking-out process can lead to increased mortality rates in the field, further increasing the costs of forest restoration.

Studies that investigate the impact of root deformation caused during the pricking-out process and its consequences for the establishment and growth of tree seedlings in the field are still in their early stages. In this study, root deformation did not affect the RGR of seedlings of the typical pioneer tropical tree S. multijuga 64 days after pricking out and subjected to different light conditions for 43 days. However, root deformation induced significant decreases in $\mathrm{RGR}_{\mathrm{R}}$, which may have

Revista Árvore 2020;44:e4418 
affected the $\mathrm{LMR}_{2}, \mathrm{D} / \mathrm{RV}$, and H/RV. From a practical point of view, our results show that root deformation caused by errors during the pricking-out process potentially makes tree seedlings more susceptible to adverse factors in the field, which can lead to reduced survival rates and growth of these seedlings. Other studies exploring the adverse and interactive effects of root deformation and environmental stress are necessary. Such studies may help to elucidate the endogenous and exogenous factors affecting tree seedling mortality in forest restoration programs and may lead to improved technical procedures for tree seedling production in tropical forest nurseries.

\section{CONCLUSIONS}

The $S$. multijuga seedlings had their growth rates severely affected in the PAR values by about $1 \mathrm{~mol}$ of photons $\mathrm{m}^{-2}$ day $^{-1}$, but root deformation did not affect the relative growth rates of the entire plant for 43 days. Instead, plants with root deformation showed a significant decrease in the relative growth rate based on the dry root mass. Changes in root growth reduced biomass allocation to the roots and increased biomass allocation to the stems and leaves. The interactive effects of low light availability and root deformation affected the allocation of leaf biomass at low light availability values. From a practical point of view, root deformations caused by pricking-out errors in forest nurseries can lead to the production of low-quality $S$. multijuga seedlings, which present less competitive capacity under a variety of light conditions.

\section{ACKNOWLEDGMENTS}

Financial support for the investigation was provided by the Universidade Estadual de Santa Cruz (UESC) (00220.1100.1843). The authors would like to thank the UESC for funding the research through the Postrectory of research and post graduation (PROPP) and the NGO Instituto Floresta Viva for providing the seeds used. Funding for Emile C. S. Lopes was provided by scholarship from the Bahia Research Support Foundation (BOL0361 / 2017). Martielly S. dos Santos thanks the National Council for Scientific and Technological Development $(\mathrm{CNPq})$ for the postdoctoral scholarship (409947 / 2017-2). Marcelo S. Mielke thanks CNPq for the scientific productivity scholarship award (305477 / 2018-8). We would like to thank Editage (www. Editage. com) for correcting the English text.

\section{REFERENCES}

Agren G, Ingestad T. Root: shoot ratios as a balance between nitrogen productivity and photosynthesis. Plant, Cell and Environment. 1987;10(7):579-86.

Amoroso G, Frangi P, Piatti R, Ferrini F, Fini A, Faoro M. Effect of container design on plant growth of little leaf linden and field elm. HortScience. 2010;45(12):1824-29.

Bazzaz FA, Pickett STA. Physiological ecology of tropical succession: a comparative review. Annual Review of Ecology and Systematic. 1980;11:287310.

Binotto AF, Dal' Col Lúcio A, Lopes SJ. Correlations between growth variables and the Dickson Quality Index in forest seedlings. Cerne. 2010;16(4):457-64.

Bizet F, Bengough AG, Hummel I, Bogeat-Triboulot MB, Dupuy LX. 3D deformation field in growing plant roots reveals both mechanical and biological responses to axial mechanical forces. Journal of Experimental Botany. 2016;67(19):5605-14.

Brancalion PHS, Chazdon RL. Beyond hectares: four principles to guide reforestation in the context of tropical forest and landscape restoration. Restoration Ecology. 2017;25(4):491-96.

Brancalion PHS, Isernhagen I, Machado RP, Christoffoleti PJ, Rodrigues RR. Seletividade dos herbicidas setoxidim, isoxaflutol e bentazon a espécies arbóreas nativas. Pesquisa Agropecuária Brasileira. 2009;44(3):251-57.

Calegari L, Martins SV, Gleriani JM, Silva E, Busato LC. Análise da dinâmica de fragmentos florestais no município de Carandaí, MG, para fins de restauração florestal. Revista Árvore. 2010;34(5):871-80.

Carneiro JG. Produção e controle de qualidade de mudas florestais. Curitiba, PR: UFPR/FUPEF; 1995 $451 \mathrm{p}$.

Carvalho PER. Pau-cigarra - Senna multijuga. Colombo, PR: Embrapa Informação Tecnológica; 2004.

César RG, Viani RAG, Silva MC, Brancalion PHS. Does a native grass (Imperata brasiliensis Trin.) limit tropical forest restoration like an alien grass (Melinis 
minutiflora P. Beauv.)? Tropical Conservation Science. 2014;7(4):639-56.

Doust S, Erskine PD, Lamb D. Direct seeding to restore rain forest species: microsite effects on the early establishment and growth of rainforest tree seedlings on degraded land in the wet tropics of Australia. Forest Ecology Management. 2006;234(1):333-43.

Duboc E, editora. Erva-Mate: parâmetros para seleção de planta matriz e área de coleta de sementes. Documentos 132. Dourado, Mato Grosso do Sul: Embrapa Agropecuária Oeste; 2015.

Farrar JF, Jones DL. The control of carbon acquisition by roots. New Phytologist. 2000;147(1):43-53.

Feijó NSA, Mielke MS, Gomes FP, França S, Lavinsky AO. Growth and photosynthetic responses of Gallesia integrifolia (Spreng.) Harms and Schinus terebinthifolius Raddi seedlings in dense shade. Agroforestry Systems. 2009;77(1): 49-58.

Ferreira LV, Parolin P, Matos D, Cunha D, Chaves PP, Neckel S. The effect of exotic Urochloa decumbens (Stapf) R. D. Webster (Poaceae) in the reduction of species richness and change floristic composition of natural regeneration in the Floresta Nacional de Carajás, Brazil. Anais da Academia Brasileira de Ciências. 2016;88(Supp.1):589-97.

Freitas TAS, Barroso DG, Carneiro JGA, Penchel RM, Lamônica KR, Ferreira DA. Desempenho radicular de mudas de eucalipto produzidas em diferentes recipientes e substratos. Revista Árvore. 2005;29(6):853-61.

Giam X. Global biodiversity loss from tropical deforestation. Proceedings of the National Academy of Sciences of the United States of America. 2017; 114(23):5775-77.

Givnish TJ. Adaptation to sun and shade: a wholeplant perspective. Australian Journal of Plant Physiology. 1988;15(2):63-92.

Gomes JM, Couto L, Leite HG, Xavier A, Ribeiro GSL. Parâmetros morfológicos na avaliação da qualidade de mudas de Eucalyptus grandis. Revista Árvore. 2002;26(6):655-64.

Gregorio N, Herbohn JL, Harrison SR. Guide to quality seedling production in smallholder nurseries [Internet]. 2010. Available from: https://www. researchgate.net/publication/44444574_Guide to_quality_seedling_production_in_smallholder nurseries

Grossnickle SC. Restoration silviculture: an ecophysiological perspective - lessons learned across 40 years C. Reforesta. 2016;1:1-36.

Jaenicke H. Good tree nursery practices: practical guidelines for research nurseries. Nairobi, Kenya: International Centre for Research in Agroforestry; 1999. ISBN: 9290591307

Kitajima K, Fenner M. Ecology of seedling regeneration. In: Fenner M, editor. Seeds: the ecology of regeneration in plant communities. 2nd ed. Wallingford: CABI Publishing; 2000. p. 331-360.

Lacerda DR, Lemos Filho JP, Goulart MF, Ribeiro RA, Lovato MB. Seed-dormancy variation in natural populations of two tropical leguminous tree species: Senna multijuga (Caesalpinoideae) and Plathymenia reticulata (Mimosoideae). Seed Science Research. 2004;14(2):127-35.

Lamb D. Forest restoration - The third big silvicultural challenge. Journal of Tropical Forest Science. 2012;24(3):295-99.

Lorenzi H. Árvores Brasileiras: manual de identificação e cultivo de plantas arbóreas do Brasil. Nova Odessa: Instituto Plantarum; 2002.

Lynch J. Root architecture and plant productivity. Plant Physiology. 1995;109:7-13.

Markesteijn L, Poorter L. Seedling root morphology and biomass allocation of 62 tropical tree species in relation to drought- and shade-tolerance. Jounal of Ecology. 2009;97(2):311-25.

McDonald AJS, Ericsson A, Lohammar T. Dependence of starch storage on nutrient availability and photon flux density in small birch (Betula pendula Roth.). Plant, Cell and Environment. 1986;9(6):311-25.

Montagnini F. Selecting tree species for plantation. In: Mansourian S, Vallauri D, Dudley N (eds). Forest restoration in landscapes. New York: Springer; 2005.

Montgomery R. Relative importance of

Revista Árvore 2020;44:e4418 
photosynthetic physiology and biomass allocation for tree seedling growth across a broad light gradient. Tree Physiology. 2004;24(2):155-67.

Ortega U, Majada J, Mena-Petite A, Sanchez-Zabala J, Rodriguez-Iturrizar N, Txarterina K, et al. Field performance of Pinus radiata D. Don produced in nursery with different types of containers. New Forests. 2006;31(1):97-112.

Poorter H, Hemkes C. Leaf area ratio and net assimilation rate of 24 wild species differing in relative growth rate. Oecologia. 1990;83(4):553-59.

Poorter H, Niklas KJ, Reich PB, Oleksyn J, Poot P, Mommer L. Biomass allocation to leaves, stems and roots: meta-analyses of interspecific variation and environmental control. New Phytologist. 2012;193(1):30-50.

R Development Core Team. R: A language and environment for statistical computing. Vienna, Austria: R Foundation for Statistical Computing; 2019. Available at: <URL https://www.R-project. $\operatorname{org} />$.

Reis GG, Reis MGF, Bernardo AL, Maestri M. Efeito da poda de raízes sobre a arquitetura do sistema radicular e o crescimento de mudas de Eucalyptus grandis e Eucalyptus citriodora produzidas em tubetes. Revista Árvore. 1991;15(1):43-54.

Resende AS, Leles, PSS, editores. Controle de plantas daninhas na restauração florestal. Brasília, DF: Embrapa; 2017. ISBN 978-85-7035-661-1.

Santos FAM, Leles PSS, Santana JES, Nascimento DF, Machado AFL. Controle químico de plantas daninhas em povoamentos de restauração florestal. Pesquisa Florestal Brasileira. 2018;38:1-9.

Scalon SPQ, Mussury RM, Euzébio VLM, Kodama FM, Kissmann C. Estresse hídrico no metabolismo e crescimento inicial de mudas de Mutambo (Guazuma ulmifolia Lam.). Ciência Florestal. 2011;21(4):65562.

Tinn-R Team. Tinn-R Editor - GUI for R Language and Environment. 2018. Available at: <URL http:// nbcgib.uesc.br/lec/software/editores/tinn-r/en>.

Thomas DS, Heagney GA, Harper P. Nursery transplant practices determine seedling root quality of two subtropical eucalypts. New Forests. 2008;36(2):125-34.

Valladares F, García-Plazaola JI, Morales F, Niinemets Ü. Photosynthetic responses to radiation. In: Flexas J, Loreto F, Medrano H, editors. Terrestrial Photosynthesis in a Changing Environment: A Molecular, Physiological, and Ecological Approach. New York: Cambridge University Press; 2012. p. 243-260.

Weidlich EWA. Desenvolvimento de espécies arbóreas nativas e competição com Brachiaria humidicola em área de restauração de floresta fluvial. [dissertation]. Curitiba: Universidade Federal do Paraná; 2011.

Wendling I, Ferrari MP, Grossi F, editors. Curso intensivo de viveiros e produção de mudas. Colombo, PR: Embrapa Florestas; 2002.

Whitmore TC. Canopy gaps and the two major groups of forest trees. Ecology. 1989;70(3):536-38.

Wilkinson KM, Landis TD, Haase DL, Daley BF, Dumroese RK, editors. Tropical nursery manual: a guide to starting and operating a nursery for native and traditional plants. Washington: Forest Service; 2014.

Zuidema PA, Dijkman W, van Rijsoort J. Crecimiento de plantines de Bertholletia excelsa HBK em función de su tamaño y la disponibilidad de luz. Ecologia en Bolívia. 1999;33:23-35. 